\title{
Treatment results, side effects and prognostic factors affecting survival in patients with larynx cancer
}

\author{
Larinks kanserli hastaların tedavi sonuçları, yan etkileri ve \\ sağkalımını etkileyen prognostik faktörler

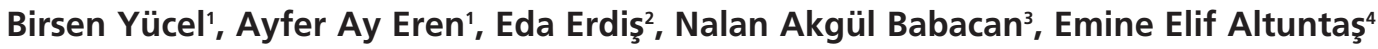 \\ ${ }^{\prime}$ Department of Radiation Oncology, Faculty of Medicine, Cumburiyet University, Sivas, Turkey \\ ${ }^{2}$ Department of Radiation Oncology, Antakya Government Hospital, Hatay, Turkey \\ ${ }^{3}$ Department of Medical Oncology, Faculty of Medicine, Cumburiyet University, Sivas, Turkey \\ ${ }^{4}$ Department of Otorbinolaryngology, Faculty of Medicine, Cumburiyet University, Sivas, Turkey
}

\begin{abstract}
Objective: Our aim was to determine the treatment results, side effects and the prognostic factors affecting survival in patients with larynx cancer treated in our clinic.

Methods: Data of a total of 90 patients with larynx carcinoma were included in the study. The patients' performance scores were evaluated according to the Eastern Cooperative Oncology Group (ECOG) system.

Results: Eighty-seven (97\%) patients were male and three patients (3\%) were female. The median age of the patients was 59 (37-86) years. Early-stage, locally advanced stage, and metastatic disease were detected in 43,55 , and $2 \%$ of the patients, respectively. Laryngeal cancers were observed in the glottic (53\%), and supraglottic (47\%) regions. Performance score $(\mathrm{p}=0.022)$, grade $(\mathrm{p}=0.033)$, lymph node metastasis $(p=0.001)$, T stage $(p=0.034)$ and disease stage $(p=0.007)$ were significantly unfavourable in supraglottic cancers compared to glottic cancers. Recurrence was observed in $17 \%$ of the patients in a median 15 (range: 5 -96) months. Distant metastasis was observed in $12 \%$ of the patients in a median 17 (range: 1-155) months. The factors affecting survival were the presence of comorbidities ( $\mathrm{p}=0.032)$, performance status $(\mathrm{p}=0.022)$, hemoglobin level $(\mathrm{p}=0.003)$, T stage $(\mathrm{p}=0.006)$, disease stage $(\mathrm{p}=0.011)$, and weight loss $(\mathrm{p}=0.002)$. When RT- and CRT-associated side effects were compared, the incidence of adverse effects such as mucositis $(\mathrm{p}<0.001)$, nausea/vomiting $(\mathrm{p}<0.001)$, weight loss $(\mathrm{p}=0.005)$, neutropenia $(\mathrm{p}=0.001)$, and anemia $(\mathrm{p}=0.003)$ in patients under chemoradiotherapy was significantly higher than those associated with radiotherapy.

Conclusion: Hemoglobin level, T stage, presence of comorbidity and weight loss were independent prognostic factors.
\end{abstract}

Key words: Larynx cancer, survival, prognosis, side effect.

\section{Özet}

Amaç: Bu çalışmada, kliniğimizde tedavi edilen larinks kanserli hastaların tedavi sonuçları, tedavilerin yan etkileri ve hastaların sağkalımını etkileyen prognostik faktörlerin belirlenmesi amaçlanmıştır.

Yöntem: Çalışmada 90 hasta verisi analiz edilmiştir. Hastaların performans statüsü 2010'da revize edilmiş Doğu Onkoloji İşbirliği Grubu (Eastern Cooperative Oncology Group, ECOG) skorlama sistemine göre değerlendirilmiştir.

Bulgular: Hastaların \%97'si erkek ve \%3'ü kadın olup, medyan yaşı 59 (37-86) idi. Erken evre \% 43, lokal ileri evre \%55, metastatik evre kanser \%2 hastada saptandı. Hastaların \% 53'ünü glottik kanserler, \%47'sini supraglottik kanserler oluşturmaktaydı. Supraglottik kanserlerin performans durumu $(\mathrm{p}=0.022)$, grade $(\mathrm{p}=0.033)$, T evresi $(\mathrm{p}=0.034)$, lenf nod metastazı $(\mathrm{p}=0.001)$, hastalık evresi $(\mathrm{p}=0.007)$ bakımından glottik kanserlere göre daha kötü özelliklere sahip olduğu saptand. Medyan 15 (dağılım: 5-96) ayda hastaların \%17'sinde nüks, medyan 17 (dağılım: 1$155)$ ayda da hastaların \%12'sinde uzak metastaz tespit edildi. Hastaların sağkalımını komorbidite $(\mathrm{p}=0.032)$, performans durumu $(\mathrm{p}=0.022)$, hemoglobin düzeyi $(\mathrm{p}=0.003), \mathrm{T}$ evresi $(\mathrm{p}=0.006)$, hastalı evresi $(\mathrm{p}=0.011)$, kilo kaybı $(\mathrm{p}=0.002)$ etkilemekteydi. Kemoradyoterapi uygulanan hastalarda mukozit $(\mathrm{p}<0.001)$, bulant kusma $(\mathrm{p}<0.001)$, kilo kayb1 $(\mathrm{p}=0.005)$, nötropeni $(\mathrm{p}=0.001)$ ve anemi $(\mathrm{p}=0.003)$, radyoterapi uygulanan hastalara göre daha fazla gözlenmiştir.

Sonuç: Hemoglobin düzeyi, T evresi, komorbidite ve kilo kaybı bu hastalar için bağımsız prognostik faktörler olmuştur.

Anahtar sözcükler: Larinks kanseri, sağkalım, prognoz, yan etki.
Correspondence: Birsen Yücel, MD. Department of Radiation Oncology, Faculty of Medicine, Cumhuriyet University, Sivas, Turkey.

e-mail: yucelbirsen@yahoo.com

Received: April 16, 2013; Accepted: May 27, 2013; Published online: November 1, 2013
Online available at:

www.jmedupdates.org doi: $10.2399 / \mathrm{jmu} .2013002005$ QR code: 
Larynx cancers are the second most common cancers of the head, and neck region, following skin cancers, and constitute $2-5 \%$ of all malignancies. ${ }^{[1]}$ According to the Surveillance, Epidemiology, and End Results data, annual incidence of larynx cancers was 3.4/100,000 between 20032007 (men, 6.1/100,000, and women, 1.3/100,000) ${ }^{[2]}$ The larynx is divided anatomically into three regions as supraglottis, glottis, and subglottis. Glottic (60-65\%), supraglottic $(30-35 \%)$, and transglottic+subglottic $(5 \%)$ tumors have been found in varying incidences. ${ }^{[3,4]}$ As in the case of all head and neck cancers, the most common histopathological type in larynx cancers is squamous cell carcinoma.

As they cause hoarseness, glottic tumors are generally diagnosed in their early-stages. However, supraglottic tumors are generally diagnosed in the late-stage, as they don't manifest many symptoms. In addition they have a rich lymphatic network which explains higher incidence of metastatic lymph nodes. ${ }^{[4,5]}$ Approximately $50-60 \%$ of larynx cancers are diagnosed in the early-stages (Stage I-II). ${ }^{[5]}$

Larynx cancers generally metastasize via direct invasion or through the lymphatic system. Therefore, surgery and radiotherapy (RT) are two important treatment modalities in these cancers. However, the role of chemotherapy (CT), which is a part of chemoradiotherapy (CRT) or induction treatment, is gradually increasing. Surgery or RT have similar local control, and survival rates in the early-stage tumors. With both treatment modalities, 5-year disease-free survival rates are approximately $90 \%$ in stage I and $80 \%$ in stage II ${ }^{[6]}$ Combination treatments (surgical and post-operative RT/CRT or primary CRT) are generally preferred for late-stage tumors.

To date, prognostic factors such as gender, age, smoking, late stage, supraglottic disease, and grade have been described in these cancers. In recent years, investigations on the importance of certain genetic and immunological markers (p53, Ki67, BNIP3, TGM2, and IGF1R) have begun. ${ }^{[7-12]}$ The aim of this study was to determine the prognostic factors which have an impact on the treatment, in addition to side effects and survival rates in patients with larynx cancer.

\section{Materials and Methods}

Patients who were admitted to the Oncology Center at Training, Research and Application Hospital of Cumhuriyet University Medical Faculty between 2006 and 2012, and treated for larynx cancer were included in the study. The patients' data were obtained from the patients' medical records.
The patients' performance scores were evaluated according to the Eastern Cooperative Oncology Group (ECOG) scoring system. Disease staging was performed according to the TNM staging, which was revised in 2010. A hemogram was performed at the time of admission, and the hemoglobin concentration was used as a criterion during the evaluation process of survival. Weight loss was defined as a $5 \%$ reduction in the patient's weight. The data were obtained by subtracting baseline bodyweight (before treatment) from the final bodyweight (after treatment) in patients who received RT or CRT, and from anamnesis in patients who received surgical treatment.

Radiothetapy was performed in all patients using a Varian Clinac DHX instrument (Varian Medical Systems, Inc., Palo Alto, CA, USA) and a 6 MV x-ray. RT planning was performed three-dimensionally using ECLIPS version 8.6 software (Varian Medical Systems, Inc., Palo Alto, CA, USA). Radiotherapy fields were determined according to the disease stage, and localization. A total dose of 60-66 Gy was given in $2 \mathrm{~Gy} /$ fractions starting from the region containing the tumor bed or neck lymph nodes to patients who were scheduled for post-operative RT. In patients with earlystage disease who were scheduled for definitive RT, a total dose of 58.5, 63, 65.25, 70 Gy RT was given in 2-2.25 Gy/day fractions or a total dose of 72-74.4 Gy was given hyperfractionatedly in $1.2 \times 2 /$ day fractions. In patients with locally advanced disease who were scheduled for definitive RT, a total dose of 70 Gy RT was given in 2 Gy/day fractions concurrently with CT. In CRT, weekly cisplatin (40 $\left.\mathrm{mg} / \mathrm{m}^{2}\right)$ or weekly cisplatin $\left(25 \mathrm{mg} / \mathrm{m}^{2}\right)+$ docetaxel $(25$ $\mathrm{mg} / \mathrm{m}^{2}$ ) schemes were used. During RT, the side effects of the treatment were evaluated weekly according to the RTOG/EORTC (Radiation Therapy Oncology Group/ European Organisation for Research and Treatment of Cancer) side effect criteria. ${ }^{[13]}$

Statistical analysis was performed using the Statistical Package for Social Sciences 15.0 for Windows (SPSS Inc., Chicago, IL, USA). Frequency tests and the chi-square test were performed. Overall survival was estimated by the Kaplan-Meier method. Multivariate analysis (Cox regression analysis) was performed to evaluate the independent factors effective on survival. $p$ values $<0.05$ were considered statistically significant.

\section{Results}

A total of 90 patients with larynx carcinoma were included in the study. Eighty-seven (97\%) patients were male and 3 patients $(3 \%)$ were female. The median age was 59 (range: 37-86) years. Demographical features of the patients are presented in Table 1 . 
Clinical, and histopathological differences between glottic and supraglottic cancers and treatment protocols according to the stage of the disease are summarized in Table 2 and Table 3. Performance score $(\mathrm{p}=0.022)$, grade $(\mathrm{p}=0.033)$, lymph node metastasis $(\mathrm{p}=0.001)$, T stage $(\mathrm{p}=0.034)$ and disease stage $(\mathrm{p}=0.007)$ were significantly different in supraglottic cancers compared to glottic cancers.

\section{Surgical Treatment}

As surgical treatments, total $(\mathrm{n}=28 ; 31 \%)$, and subtotal laryngectomies $(\mathrm{n}=11 ; 12 \%)$, cordectomy $(\mathrm{n}=3 ; 3 \%)$, functional $(\mathrm{n}=17 ; 49 \%)$, and modified radical $(\mathrm{n}=18 ; 51 \%)$ neck dissections were performed.

\section{RT and CRT}

The median RT doses were 70 Gy, and 60 Gy in patients who received definitive or adjuvant RT, respectively. Cisplatin protocol was implemented on 17 patients $(61 \%)$ who received CRT, and cisplatin+docetaxel protocol was applied on 11 patients (39\%) who received CRT.

The mean follow-up period was 22 (range: 1-158) months. Recurrence was observed in 15 patients within a median 15 (range: 5-96) months. Recurrence was observed in 5 out of 39 patients (13\%) with early-stage, and in 10 out of 49 patients $(20 \%)$ with locally advanced stage disease $(\mathrm{p}=0.258)$. Recurrence was detected in the tumor bed in 7 $(78 \%)$, and in the neck in 2 patients (22\%). Recurrences were noted in patients who received surgical treatment $(\mathrm{n}=5 ; 38 \%)$, CRT $(\mathrm{N}=5 ; 31 \%)$, surgery+RT $(\mathrm{n}=2 ; 17 \%)$, surgery+RT $(n=2 ; 12 \%)$, and RT $(n=1 ; 4 \%)$.
Table 1. Demographic characteristics of the patients and the disease states.

\begin{tabular}{llc}
\hline & & Patients, $\mathbf{n}(\%)$ \\
\hline Sex & Male & $87(97)$ \\
Smoking & Female & $3(3)$ \\
Alcohol use & & $83(92)$ \\
Family history & & $23(26)$ \\
Comorbidity & & $27(30)$ \\
Performance status & ECOG-0 & $33(37)$ \\
& ECOG-1 & $56(62)$ \\
Hemoglobin & $\geq 12$ mg/dl & $34(38)$ \\
& $\geq 12$ mg/dl & $62(69)$ \\
Weight loss & & $28(31)$ \\
Localization of the tumour & Glottic & $36(40)$ \\
& Supraglottic & $48(53)$ \\
Histopathology & In situ carcinoma & $42(47)$ \\
& Squamous cell carcinoma & $3(3)$ \\
Grade & Grade I & $87(97)$ \\
& Grade II & $26(32$ \\
& Grade III & $44(55)$ \\
Levels of lymph node & Level I & $10(13)$ \\
involvement & Level II & $5(6)$ \\
& Level III & $21(23)$ \\
& Level IV & $10(13)$ \\
Lisease stage & Level V & $4(4)$ \\
& Early stage (I-II) & $4(4)$ \\
& Locally advanced stage (III-IV) & $39(43)$ \\
& Metastatic stage & $2(2)$ \\
\hline
\end{tabular}

Metastasis was observed in 14 patients (12\%) within the median17 months (1-155 months). Eight metastatis foci $(57 \%)$ were in the lung, $4(29 \%)$ in the bone, 1 (7\%) in the

Table 2. Clinical and histopathological differences in glottic and supraglottics cancers, according to stage of the disease, locations of tumors, and treatment modalities.

\begin{tabular}{|c|c|c|c|c|}
\hline & & Glottic $(n=48)$ & Supraglottic $(n=42)$ & $p$ value \\
\hline Performance status & $\begin{array}{l}\text { ECOG0 } \\
\text { ECOG1 }\end{array}$ & $\begin{array}{l}35(68) \\
13(38)\end{array}$ & $\begin{array}{l}21(38) \\
21(62)\end{array}$ & 0.022 \\
\hline Hemoglobin & $\begin{array}{l}\geq 12 \mathrm{mg} / \mathrm{dl} \\
\geq 12 \mathrm{mg} / \mathrm{dl}\end{array}$ & $\begin{array}{l}36(58) \\
12(43)\end{array}$ & $\begin{array}{l}26(42) \\
16(57)\end{array}$ & 0.133 \\
\hline Grade & $\begin{array}{l}\text { Grade } 1 \\
\text { Grade } 2 \\
\text { Grade } 3\end{array}$ & $\begin{array}{c}19(73) \\
18(41) \\
5(50)\end{array}$ & $\begin{array}{c}7(27) \\
26(59) \\
5(50)\end{array}$ & 0.033 \\
\hline T stage & $\begin{array}{l}\text { T1-2 } \\
\text { T3-4 }\end{array}$ & $\begin{array}{l}27(63) \\
18(41)\end{array}$ & $\begin{array}{l}16(37) \\
26(59)\end{array}$ & 0.034 \\
\hline Lymph node involvement & $\begin{array}{l}\text { Present } \\
\text { Absent }\end{array}$ & $\begin{array}{l}41(64) \\
7(28)\end{array}$ & $\begin{array}{l}23(36) \\
18(72)\end{array}$ & 0.001 \\
\hline Stage & $\begin{array}{l}\text { Early stage (I-II) } \\
\text { Locally advanced stage (III-IV) }\end{array}$ & $\begin{array}{l}27(69) \\
20(41)\end{array}$ & $\begin{array}{l}12(31) \\
29(59)\end{array}$ & 0.007 \\
\hline
\end{tabular}


Table 3. Treatment modalities in glottic and supraglottic cancers according to the disease stages.

\begin{tabular}{llccc}
\hline & & Glottic $(\mathbf{n = 4 8 )}$ & Supraglottic $(\mathbf{n = 4 2 )}$ & Total \\
\hline Treatment of early stage & Surgery & $5(19)$ & $7(58)$ & $12(31)$ \\
& RT* $^{*}$ & $22(78)$ & $5(42)$ & $27(67)$ \\
Treatment of locally advanced stage & Surgery & $1(5)$ & - & $1(2)$ \\
& Radiotherapy & - & $2(8)$ & $2(4)$ \\
& CRT $^{+}$ & $5(25)$ & $11(42)$ & $16(33)$ \\
& Surgery +RT/CRT & $14(70)$ & $13(50)$ & $27(55)$ \\
\hline
\end{tabular}

${ }^{*} \mathrm{RT}$ : Radiotherapy, ${ }^{\dagger} \mathrm{CRT}$ : Chemoradiotherapy

brain, and $1(7 \%)$ in the mediastinum. Distant metastases were observed in $5(13 \%)$ patients with early-stage and in 6 $(12 \%)$ cases with locally advanced stage $(\mathrm{p}=0.592)$.

Secondary metastases of primary malignancies developed in 8 (9\%) patients. These primary malignancies were pulmonary squamous cell carcinoma $(\mathrm{n}=4 ; 50 \%)$, renal cell carcinoma ( $\mathrm{n}=1 ; 13 \%)$, rectal adenocarcinoma $(\mathrm{n}=1 ; 13 \%)$, gastric cancer $(\mathrm{n}=1 ; 13 \%)$, and skin basal cell carcinoma $(\mathrm{n}=1 ; 13 \%)$

Three-year overall survival rate was $69 \%$ for all patients, while the median survival rate was not calculated. The factors affecting survival in the univariate analysis were the presence of comorbidity $(\mathrm{p}=0.032)$, ECOG performance score $(\mathrm{p}=0.022)$, hemoglobin level $(\mathrm{p}=0.003), \mathrm{T}$ stage $(\mathrm{p}=0.006)$, disease stage $(\mathrm{p}=0.011)$, and weight loss $(\mathrm{p}=0.002)$. The factors affecting survival rates independently in the multivariate analysis were hemoglobin level $(\mathrm{p}=0.002), \mathrm{T}$ stage $(\mathrm{p}=0.026)$, presence of comorbidity $(\mathrm{p}=0.001)$, and weight loss $(\mathrm{p}<0.001)$. The prognostic factors affecting survival in larynx cancer are presented in Tables 4 and 5.

Radiotherapy- and CRT-associated side effects were observed in 77 patients (85\%). Radiotherapy was interrupted in 13 of these patients (14\%) due to the side effects of RT and CRT. When RT- and CRT-associated side effects were compared, the incidence of mucositis $(\mathrm{p}<0.001)$, nausea/vomiting $(\mathrm{p}<0.001)$, weight loss $(\mathrm{p}=0.005)$, neutrope-

Table 4. Univariate analysis of the prognostic factors affecting survival in laryngeal cancer.

\begin{tabular}{|c|c|c|c|c|}
\hline & & No. patients & 3-year overall survival rates (\%) & $p$ value \\
\hline Comorbidity & $\begin{array}{l}\text { Absent } \\
\text { Present }\end{array}$ & $\begin{array}{l}57 \\
33\end{array}$ & $\begin{array}{l}76 \\
43\end{array}$ & 0.032 \\
\hline Performance status & $\begin{array}{l}\text { ECOG } 0 \\
\text { ECOG I }\end{array}$ & $\begin{array}{l}56 \\
34\end{array}$ & $\begin{array}{l}79 \\
55\end{array}$ & 0.022 \\
\hline Localization & $\begin{array}{l}\text { Glottic } \\
\text { Supraglottic }\end{array}$ & $\begin{array}{l}48 \\
42\end{array}$ & $\begin{array}{l}75 \\
58\end{array}$ & 0.132 \\
\hline Hemoglobin & $\begin{array}{l}\geq 12 \mathrm{~g} / \mathrm{dL} \\
\geq 12 \mathrm{~g} / \mathrm{dL}\end{array}$ & $\begin{array}{l}28 \\
62\end{array}$ & $\begin{array}{l}47 \\
76\end{array}$ & 0.003 \\
\hline Grade & $\begin{array}{l}\text { Grade I } \\
\text { Grade II } \\
\text { Grade III }\end{array}$ & $\begin{array}{l}26 \\
44 \\
10\end{array}$ & $\begin{array}{l}66 \\
69 \\
38\end{array}$ & 0.291 \\
\hline T stage & $\begin{array}{l}\text { T1-2 } \\
\text { T3-4 }\end{array}$ & $\begin{array}{l}43 \\
44\end{array}$ & $\begin{array}{l}81 \\
56\end{array}$ & 0.006 \\
\hline Lymph node status & $\begin{array}{l}\mathrm{NO} \\
\mathrm{N}+\end{array}$ & $\begin{array}{l}63 \\
24\end{array}$ & $\begin{array}{l}71 \\
62\end{array}$ & 0.426 \\
\hline Disease stage & $\begin{array}{l}\text { Early stage } \\
\text { Locally advanced stage }\end{array}$ & $\begin{array}{l}39 \\
49\end{array}$ & $\begin{array}{l}83 \\
61\end{array}$ & 0.011 \\
\hline $\mathrm{RT}^{*}$ interruption & $\begin{array}{l}\text { No } \\
\text { Yes }\end{array}$ & $\begin{array}{l}66 \\
13\end{array}$ & $\begin{array}{l}74 \\
56\end{array}$ & 0.179 \\
\hline Weight loss & $\begin{array}{l}\text { No } \\
\text { Yes }\end{array}$ & $\begin{array}{l}54 \\
36\end{array}$ & $\begin{array}{l}78 \\
52\end{array}$ & 0.002 \\
\hline
\end{tabular}

*RT: Radiotherapy 
Table 5. Multivariate analysis of the prognostic factors affecting survival in laryngeal cancer.

\begin{tabular}{llccc}
\hline & p value & HR $^{*}$ & \%95 $\mathbf{C l}^{+}$ \\
\hline Multivariate analysis & T3-4 & 0.026 & 2.64 & $1.12-6.20$ \\
& Presence of Comorbidity & 0.001 & 4.49 & $1.88-10.73$ \\
& Weight loss & 0.001 & 5.98 & $2.50-14.28$ \\
& Hemoglobin $\geq 12 \mathrm{~g} / \mathrm{dL}$ & 0.002 & 0.30 & $0.14-0.64$ \\
\hline
\end{tabular}

${ }^{*} \mathrm{HR}$ : Hazard ratio, ${ }^{+} \mathrm{Cl}$ : Confidence interval

nia $(\mathrm{p}=0.001)$, and anemia $(\mathrm{p}=0.003)$ was significantly higher among CRT-associated side effects. The comparison of RTand CRT-associated side effects is presented in Table 6.

\section{Discussion}

Larynx carcinoma is the second most common cancer among the head, and neck cancers. The incidence of larynx cancers is higher in males compared to females. Şengül et al. determined that among 323 patients with larynx cancer only $3 \%$ of them were of female gender, whereas Raitiola et al. found that female cases had constituted only $5 \%$ of 312 patients with larynx cancer. ${ }^{[14,15]}$ Similar to previous studies, $3 \%$ of the patients were of female gender in the current study.

Larynx cancers with glottic and supraglottic localization differ as for incidence, tumor features, clinical progression, and histopathological features. One of the most important factors underlying these differences is the rich lymphatic network in the supraglottic region. Many researchers stated that glottic cancers have higher incidence rates compared to supraglottic cancers. ${ }^{[1,15]}$ Raitiola et al. reported that larynx cancers were observed in the glottic, and supraglottic localizations in 57, and $43 \%$ of the cases, respectively. Şengül et al. reported that larynx cancers were localized in the glottis in $52 \%$ of the cases, and followed by in the descending order of frequency they are seen in supraglottis (32\%), and transglottis $(16 \%)$. Since the lymphatic drainage of both regions is different, the incidence of lymph node metastasis of these regions is not similar. The incidence of neck-lymph node metastasis in glottic cancers is below $10 \%$, while it ranges between $10-50 \%$ in supraglottic cancers. ${ }^{[16-18]}$ Raitiola et al. demonstrated that both regions showed differences in their $T$ stages, and stated that supraglottic cancers had significantly higher T stages. In this study, glottic, and supraglottic localizations were observed in $53 \%$, and $47 \%$ of the patients, respectively. Metastasis to the neck lymphatic sys-

Table 6. Comparison of RT- and CRT-induced side effects.

\begin{tabular}{|c|c|c|c|c|c|}
\hline & & & $R T$ * $(n=44)$ & $\mathrm{CRT}^{+}(\mathrm{n}=28)$ & $p$ value \\
\hline \multirow[t]{8}{*}{ Early side effects } & Skin & $\begin{array}{l}\text { Grade 1-2 } \\
\text { Grade 3-4 }\end{array}$ & $\begin{array}{c}38(86) \\
2(5)\end{array}$ & $\begin{array}{c}24(86) \\
3(11)\end{array}$ & 0.430 \\
\hline & Mucositis & $\begin{array}{l}\text { Grade } 1-2 \\
\text { Grade } 3-4\end{array}$ & $\begin{array}{c}14(32) \\
-\end{array}$ & $\begin{array}{c}19(68) \\
6(21)\end{array}$ & $<0.001$ \\
\hline & Pharynx/osephagus & $\begin{array}{l}\text { Grade } 1-2 \\
\text { Grade } 3-4\end{array}$ & $\begin{array}{c}32(73) \\
1(2)\end{array}$ & $\begin{array}{c}22(79) \\
1(4)\end{array}$ & 0.750 \\
\hline & Neutropenia & $\begin{array}{l}\text { Grade } 1-2 \\
\text { Grade } 3-4\end{array}$ & $\begin{array}{c}1(2) \\
-\end{array}$ & $\begin{array}{l}7(25) \\
3(11)\end{array}$ & 0.001 \\
\hline & Thrombocytopenia & $\begin{array}{l}\text { Grade } 1-2 \\
\text { Grade 3-4 }\end{array}$ & - & $\begin{array}{l}1(4) \\
1(4)\end{array}$ & 0.199 \\
\hline & Anemia & $\begin{array}{l}\text { Grade } 1-2 \\
\text { Grade } 3-4\end{array}$ & $\begin{array}{c}3(7) \\
-\end{array}$ & $\begin{array}{c}10(36) \\
-\end{array}$ & 0.003 \\
\hline & Nausea/vomiting & & $13(29)$ & $24(86)$ & $<0.001$ \\
\hline & Weight loss & & $11(39)$ & $17(61)$ & 0.005 \\
\hline Late side effects & Xerostomia & $\begin{array}{l}\text { Grade } 1-2 \\
\text { Grade } 3-4\end{array}$ & $\begin{array}{c}19(43) \\
1(2)\end{array}$ & $\begin{array}{c}18(64) \\
2(7)\end{array}$ & 0.080 \\
\hline
\end{tabular}

${ }^{*}$ RT: Radiotherapy, ${ }^{+}$CRT: Chemoradiotherapy 
tem was observed in $15 \%$ of the glottic cancers and $43 \%$ in supraglottic cancers. The observed difference in metastasis was also statistically significant. Additionally, supraglottic cancers were associated with poorer patient performance scores, tumor grade, $\mathrm{T}$, and disease stages compared to glottic cancers.

Given the fact that supraglottic cancers have more invasive phenotypes compared to glottic cancers, it is believed that supraglottic cancers generally have a poorer prognosis. ${ }^{[19]}$ The high incidence of lymphatic node metastases in supraglottic cancers may be one of the underlying reasons of this deterioration. In a study of 196 patients with laryngeal squamous cell carcinoma, Teppo et al. stated that the prognosis of glottic and supraglottic cancers were different. In their study, 5-year disease-specific survival rate was over $75 \%$ in 57 patients with glottic cancer, whereas this rate was $22 \%$ in patients with supraglottic cancer. ${ }^{[10]}$ Raitiola et al. reported that the 5-year disease-specific survival rate was $81 \%$ in glottic cancers and $71 \%$ in supraglottic cancers. ${ }^{[15]}$ Different from the study by Teppo et al., there was no significant difference in the 5-year disease-specific survival rates between glottic and supraglottic cancers in the study by Raitiola et al. Similar to the results of Raitiola et al., there was no correlation between tumor localization and survival rates in this study. However, the 3 -year overall survival rate of the patients with supraglottic cancer was lower compared to patients with glottic cancer.

Survival rates in the early-stage larynx cancers are higher relative to the patients with late-stage disease. According to the literature, survival rates for early (stages I and II), and late stage (stages III and IV) larynx cancers range between $73-92 \%$ and $35-64 \%$, respectively. ${ }^{[20-22]}$ Şengül et al. reported that in the 50th month after the onset of therapy, the cumulative survival rate estimated for 172 patients in all disease stages was 69 percent. The cumulative survival rates in various disease stages were as follows: Stage I, 84\%; II, $77 \%$; III, 68\%, and IV, 56\%. ${ }^{[14]}$ Zhang et al. reported that the 3-year disease-free survival rates were as follows in 205 patients with squamous cell larynx carcinoma under surgical treatment: Stage 1, 80\%; II, $81 \%$; III, $77 \%$, and IV, $53 \%{ }^{[23]}$ Similarly, the 3 -year overall survival rates in the current study was $69 \%$ for all patients, $83 \%$ for early-stage, and $61 \%$ for late-stage disease .

According to the literature, recurrence rates range between $5-27 \%$ in the early-stage larynx cancers. ${ }^{[2,25]}$ Mercante et al. reported that the recurrence rate was $15 \%$ within a average of 16 months in 143 patients with earlystage glottic larynx cancer under radiotherapy. ${ }^{[26]}$ Çaloğlu et al. determined that $27 \%$ of 34 patients with larynx cancer who received surgery+RT and $35 \%$ of 26 patients under curative RT had experienced recurrences in a median 18 months. ${ }^{[2]}$ Ataman et al. observed that $13 \%$ of 144 patients with early-stage larynx cancer (Tis, T1 and T2) had recurrences $(33,78$, and $83 \%$ within the first one, two, and three years, respectively). ${ }^{[2]}$ In the RTOG 91-11 study (locally advanced stage, $\mathrm{n}=547)$, the authors observed recurrences in patients under induction CT+RT (70/ 173), CT+RT+CRT (34/172), and radiotherapy (80/ 173$)$ and in $32 \%$ of all patients. ${ }^{[29]}$ Parallel to the literature findings, recurrence was observed in $17 \%$ of the patients in a median 15 months in this study. Thirteen percent of the recurrences were observed in the early-stage, and $20 \%$ of them in the locally advanced stage. According to the treatment type, the lowest recurrence rate was $4 \%$ which was observed in patients who received $\mathrm{RT}$.

According to the early results of the RTOG 91-11 study (late-stage, $n=547$ ) distant metastasis was observed in $3 \%$ of all patients, in $5 \%$ of 173 patients who received induction $\mathrm{CT}+\mathrm{RT}$, in $5 \%$ of 172 patients under concomitant CRT, and in $9 \%$ of 173 patients who were given $\mathrm{RT}^{\left[{ }^{[29]} \text { Regarding }\right.}$ the RTOG 9501 study, Cooper et al. reported that the incidence of distant metastasis was $23 \%$ in patients with larynx cancer who received post-operative RT, whereas Bernier et al. reported that this rate was 25 percent. ${ }^{[30,31]}$ Çaloğlu et al., on the other hand, stated that the incidence of distant metastasis was $18 \%$ in the patient group that received postoperative RT. ${ }^{[27]}$ In this study, distant metastasis was observed in $12 \%$ of the cases in a median 17 months, and most of the metastases were present in the lung. Metastasis was observed in $13 \%$ of the patients in the early-stage and in $12 \%$ of the patients in the locally advanced stage; there was no significant difference between both groups as for the occurrence of metastasis.

The standardized incidence of developing second primary malignancy in head-neck cancers is 2.18 (95\% CI, 2.15-2.21) and the most frequent regions of second primary malignancies are esophagus and lungs. ${ }^{[3,33]}$ According to the literature, the incidence of second primary malignancy in larynx cancers ranges between $11-29 \% .{ }^{[34-36]}$ In a populationbased study performed between 1986-2008, Liao et al. determined that 9,996 patients out of 93,891 patients with head neck cancer $(11 \%)$ had second primary malignancies. In this study, the most frequent organ associated with the second primary malignancy was the nasopharynx (39\%), whereas this frequency was $14 \%$ for the larynx. ${ }^{[37]}$ Mehdiyev et al. determined that this rate was $3 \%$ in 629 patients with larynx cancer. ${ }^{[38]}$ In this study, second primary malignancies were observed in $9 \%$ of the patients, and similar to the previous studies, second malignancy developed in the lung (50\%). 
Various patient- and disease-related factors affect the survival rates in larynx cancers. Teppo et al. stated that the tumor region (glottic-supraglottic) and the disease stage affected the patient's prognosis. ${ }^{[10]}$ Esassolak et al. reported that $\mathrm{T}$ stage and RT interruption for more than five days were prognostic factors for the disease survival in 83 patients with glottic cancer who were given curative RT. ${ }^{[39]}$ Zhang et al. demonstrated that the surgical margin, disease stage and comorbidity were the independent factors that affected the prognosis of 205 patients with larynx cancer under surgical treatment. ${ }^{[25]}$ Rutkowski et al. stated that female gender, hemoglobin concentration, and body-mass index were the independent prognostic factors for overall survival in 78 patients who had T2 supraglottic cancer. ${ }^{[40]}$ In this study, patient comorbidity, performance score, weight loss, hemoglobin level, $\mathrm{T}$ stage, and disease stage were the prognostic factors for survival. However, tumor localization, RT interruption, lymph node condition, and grade did not affect survival. Hemoglobin level, T stage, comorbidity, and weight loss were also independent prognostic factors for the patients. These results indicate that early diagnosis and the overall condition of the patients are important parameters for patient survival.

In the RTOG 91-11 study, the induction CT+RT, concomitant CRT, and RT only groups were compared and evaluated for the acute side effects in these three groups. When concomitant CRT and RT groups were compared, the incidence of Grade 3 and 4 hematological side effects, mucositis, pharyngeal/esophageal side effects, and nausea were higher in the concomitant CRT relative to RT group. When concomitant CRT group was considered, Grade 3 and 4 hematological side effects were observed in $47 \%$ of the patients. Other adverse effects including mucositis (43\%), pharyngeal/esophageal (35\%), laryngeal (18\%), dermatological (7\%) side effects, nausea-vomiting $(20 \%)$ were also observed with incidence rates indicated in parentheses. In the RT group, Grade 3 and 4 hematological side effects (3\%), mucositis (24\%), pharyngeal/esophageal (19\%), laryngeal $(16 \%)$, dermatological $(9 \%)$ side effects were noted as indicated. In this group nausea and vomiting was not observed. ${ }^{[2]]}$ According to the long-term results of the same study, the most frequent long-term side effects for all three groups were related to subcutaneous tissue, salivary gland, pharynx/esophagus, and larynx. The incidence rates of 10-year cumulative grade 3-4 side effects were also determined for patients receiving CT+RT $(31 \%)$, concomitant CRT (33\%), and RT (38\%) protocols. ${ }^{[41]}$ In this study, the incidence of side effects including mucositis, nausea-vomiting, weight loss, neutropenia, and anemia was higher in patients who received CRT rather than RT. The incidence of xerostomia was similar in patients who received RT or CRT.

The limitations of the present study include its short follow-up period, retrospective design of the study and the scarce number of patients included in the study.

\section{Conclusion}

In the present study, 3 -year overall survival rate was $83 \%$ in the early, and $61 \%$ in the locally advanced stage disease, while the independent prognostic factors were hemoglobin levels, weight loss, $\mathrm{T}$ stage, and comorbidity. The frequency of treatment-associated side effects was higher in patients who received CRT relative to RT.

\section{References}

1. Higgins KM, Wang JR. State of head and neck surgical oncology research-a review and critical appraisal of landmark studies. Head Neck 2008;30:1636-42.

2. Altekruse S, Kosary C, Krapcho M, et al. SEER cancer statistics review 1975-2007. Bethesda, MD: National Cancer Institute; 2010.

3. Rosai J. Larynx and trachea. In: Rosai J, editor. Ackerman's surgical pathology. St. Louis: Mosby; 1996. p. 314-32.

4. Hoffman HT, Porter K, Karnell LH, et al. Laryngeal cancer in the United States: changes in demographics, patterns of care, and survival. Laryngoscope 2006;116:1-13.

5. Dirix P, Lambrecht M, Nuysts S. Radiotherapy for laryngeal squamous cell carcinoma: Current standards. Expert Rev Anticancer Ther 2010;10:1461-9.

6. Tamura Y, Tanaka S, Asato R, et al. Therapeutic outcomes of laryngeal cancer at Kyoto, University Hospital for 10 years. Acta Otolaryngol Suppl 2007;557:62-5.

7. Agudelo D, Quer M, Leon X, Diez S, Burgues J. Laryngeal carcinoma in patients without a history of tobacco and alcohol use. Head Neck 1997;19:200-4.

8. Boffetta P, Merletti F, Faggiano F, et al. Prognostic factors and survival of laryngeal cancer patients from Turin, Italy. A population-based study. Am J Epidemiol 1997;145:1100-5.

9. Hirvikoski P, Kumpulainen E, Virtaniemi J, et al. p53 expression and cell proliferation as prognostic factors in laryngeal squamous cell carcinoma. J Clin Oncol 1997;15:3111-20.

10. Teppo H, Soini Y, Melkko J, Koivunen P, Alho OP. Prognostic factors in laryngeal carcinoma: the role of apoptosis, $\mathrm{p} 53$, proliferation (Ki-67) and angiogenesis. APMIS 2003;111:451-7.

11. Jin T, Lin HX, Lin H, et al. Expression TGM2 and BNIP3 have prognostic significance in laryngeal cancer patients receiving surgery and postoperative radiotherapy: a retrospective study. J Transl Medicine 2012;10:64.

12. Mountzios G, Kostopoulos I, Kotoula V, et al. Insulin-like growth factor 1 receptor (IGF1R) expression and survival in operable squamous-cell laryngeal cancer. PloS One 2013;8(1):e54048.

13. Cox JD, Stetz J, Pajak TF. Toxicity criteria of the Radiation Therapy Oncology Group (RTOG) and the European Organisation for Research and Treatment of Cancer (EORTC). Int J Radiat Oncol Biol Phys 119;31:1341-6. 
14. Şengül E, Bağlam T, Çevik C, et al. The relationship between the frequency of cervical metastases and tumor related factors in laryngeal cancer and outcome of surgical treatment in these cases. [Article in Turkish] Journal of Clinical and Experimental Investigations 2012;3:214-22.

15. Raitiola H, Pukander J, Laippala P. Glottic and supraglottic laryngeal carcinoma: differences in epidemiology, clinical characteristics and prognosis. Acta Otolaryngol 1999;119:847-51

16. Hao SP, Myers EN. T3 Glottic carsinoma revisited, transglottic vs pure glottic carsinoma. Arch Otolaryn-gol 1995;121:166-70.

17. Cosselin BJ, Gullane PJ. Cancer of the larynx, para $\neg$ nasal sinuses and temporal bone. In: Lee KJ, editor. Essential otolaryngology head and neck surgery. Sixth ed. Norwaik, CT: Appleton and Lange; 1995. Chapter 29, p. 555-80.

18. Kowalski LP, Franco EL, de Andrade Sobrinho J. Factors influencing regional lymph node metastasis from laryngeal carcinoma. Ann Oto Rhino Laryngol 1995; 104:442-7.

19. Silvestri F, Bussani R, Stanta G, Cosatti C, Ferlito A. Supraglottic versus glottic laryngeal cancer: epidemiological and pathological aspects. ORL J Otorhinolaryngol Relat Spec 1992;54:43-8.

20. Hoffman HT, Porter K, Karnell LH, et al. Laryngeal cancer in the United States: changes in demographics, patterns of care, and survival. Laryngoscope 2006;116:1-13.

21. Gourin CG, Conger BT, Porubsky ES, Sheils WC, Bilodeau PA, Coleman TA. The effect of treatment on survival in patients with advanced laryngeal carcinoma. Laryngoscope 2009;119:1312-7.

22. Berrino F, De Angelis R, Sant M, et al. Survival for eight major cancers and all cancers combined for European adults diagnosed in 1995-99: results of the EUROCARE-4 study. Lancet Oncol 2007; 8:773-83.

23. Zhang SY, Zhong ML, Luo XN, et al. Retrospective analysis of prognostic factors in 205 patients with larengeal squamous cell carcinoma who underwent surgical treatment. PloS One 2013; 8(4):e60157.

24. Mendenhall WM, Hinerman RW, Amdur RJ, Mancusco AA, Villaret DB, Robbins KT. Larynx. In: Perez CA, Brady LW, Halperin EC, Schmidt-Ullrich RK, editors. Principles and practice of radiation oncology. 4th ed. Philadelphia: Lippincott Williams\& Wilkins; 2004. p. 1094-116.

25. Chen MF, Chang JT, Tsang NM, Liao CT, Chen WC. Radiotherapy of early-stage glottic cancer: analysis of factors affecting prognosis. Ann Otol Rhinol Laryngol 2003;112:904-11.

26. Mercante G, Bacciu A, Banchini L, Moretto E, Oretti, Ferri T. Salvage surgery after radiation failure in squamous cell carcinoma of the larynx. B-ENT 2005;1:107-11.

27. Çaloğlu M, Yürüt Çaloğlu V, Uzal C, Karagöl H, Tokatlı F, Uygun K. Prognostic factors and treatment results in laryngeal carcinoma: Department of Radiation Oncology of Trakya University Medical School experience. [Article in Turkish] Türk Onkoloji Dergisi 2005;20:20-6.
28. Uruk Ataman Ö, Akman F, Dağ N, et al. Treatment results of definitive radiotherapy in 144 early stage larynx carcinoma. [Article in Turkish] Türk Onkoloji Dergisi 2006;21:143-50.

29. Forastiere AA, Goepfert H, Maor M, et al. Concurrent chemotherapy and radiotherapy for organ preservation in advanced laryngeal cancer. N Engl J Med 2003;349:2091-8.

30. Cooper JS, Pajak TF, Forastiere AA, et al.; Radiation Therapy Oncology Group 9501/Intergroup. Postoperative concurrent radiotherapy and chemotherapy for high-risksquamous-cell carcinoma of the head and neck. N Engl J Med 2004;350:1937-44.

31. Bernier J, Domenge C, Ozsahin M, et al.; European Organization for Research and Treatment of Cancer Trial 22931. Postoperative irradiation with or without concomitant chemotherapy for locally advanced head and neck cancer. N Engl J Med 2004;350:1945-52.

32. Morris LGT, Sikora AG, Patel SG, Hayes RB, Ganly I. Second Primary Cancers After an Index Head and Neck Cancer: SubsiteSpecific Trends in the Era of Human Papillomavirus-Associated Oropharyngeal Cancer. J Clin Oncol 2011;29:739-46.

33. Licciardello JT, Spitz MR, Hong WK. Multiple primary cancer in patients with cancer of the head and neck: second cancer of the head and neck, esophagus, and lung. Int J Radiat Oncol Biol Phys 1989;17:467-76.

34. Fujita M, Rudoltz MS, Canady DJ, et al. Second malignant neoplasia in patients with $\mathrm{T} 1$ glottic cancer treated with radiation. Laryngoscope 1998;108:1853-5.

35. McDonald S, Haie C, Rubin P, Nelson D, Divers LD. Second malignant tumors in patients with laryngeal carcinoma: diagnosis, treatment, and prevention. Int J Radiat Oncol Biol Phys 1989;17: 457-65.

36. Holland JM, Arsanjani A, Liem BJ, Hoffelt SC, Cohen JI, Stevens KR Jr. Second malignancies in early stage laryngeal carcinoma patients treated with radiotherapy. J Laryngol Otol 2002;116:1903.

37. Liao LJ, Chou HW, Wang CT, Chung CS, Lai MS. The impact of second primary malignancies on head and neck cancer survivors: a nationwide cohort study. PloS One 2013; 8(4):e62116.

38. Mehdiyev H, Gökcan MK, Doğan M, Demirtaş M. Second primary malignites in 629 patients with laryngeal carcinoma. [Article in Turkish] Cumhuriyet Medical Journal 2010;32:331-3.

39. Esassolak M, Dubova S, Kamer S, Aydın B. Curative radiotherapy in early stage glottic laryngeal carcinoma. [Article in Turkish] Türk Onkoloji Dergisi 2006;21:28-36.

40. Rutkowski T, Wygoda A, Sk6adowski K, et al. Predictors of radiotherapy outcome in patients with T2 supraglottic carcinoma. Eur Arch Otorhinolaryngol 2012;269:923-9.

41. Forastiere AA, Zhang Q, Weber RS, et al. Long-term results of RTOG 91-11: a comparison of three nonsurgical treatment strategies to preserve the larynx in patients with locally advanced larynx cancer. J Clin Oncol 2013;31:845-52.

This is an open access article distributed under the terms of the Creative Commons Attribution-NonCommercial-NoDerivs 3.0 Unported (CC BYNC-ND3.0) Licence (http://creativecommons.org/licenses/by-nc-nd/3.0/) which permits unrestricted noncommercial use, distribution, and reproduction in any medium, provided the original work is properly cited.

Please cite this article as: Yücel B, Ay Eren A, Erdiş E, Akgül Babacan N, Altuntaş EE. Treatment results, side effects and prognostic factors affecting survival in patients with larynx cancer. J Med Updates 2013;3(2):69-76. 